\title{
Consumer Satisfaction Online Ojek Services In Indonesia: Effect of Service Quality And Customer Value
}

\author{
Viniyati Maftuchah \\ STIE Muhammadiyah, Jakarta, Indonesia \\ Ade Ghofir \\ STIE Kusuma Negara, Jakarta, Indonesia
}

Sabil

Bina Sarana Informatika Univesity, Jakarta, Indonesia

Dinar Riftiasari

Bina Sarana Informatika Univesity, Jakarta, Indonesia

\begin{abstract}
The shift of the use of conventional transportation to online transportation networks has resulted in a decrease in the market share of conventional transportation. The design of this study is causal research, which explains causal relationships between research variables to determine the causal relationship pattern of the independent variables on the dependent variable. The variables in this study are the service quality of the independent variable, customer satisfaction of the dependent variable, and the value of the customer intervening variable. Samples obtained by 100 respondents and taken by Purposive Sampling. The number of samples in this study was determined by the SEM analysis method where the number of indicators multiplied by five. Analysis of the data used is SmartPLS version 3.2. The results showed that all hypotheses could be accepted, where service quality had a positive and significant effect on customer value, but the effect of service quality on customer satisfaction had positive but not significant results, customer value had a positive and significant effect on customer satisfaction and service quality had a positive and significant effect to customer satisfaction through customer value.
\end{abstract}

Keywords: Service quality, customer value and customer satisfaction

\section{INTRODUCTION}

The development of the internet in the digital era is increasing rapidly in Indonesia. The number of internet users has increased significantly each year, currently in 2018 Indonesia ranks third in Asia as the largest internet user (Suleman, 2018). So that the birth of a new business system was developed to be able to participate in current changes (Suleman, Sutawidjaya, \& Kurniadi, 2018). The digital revolution creates very important changes in many aspects of our lives in ways never imagined. Conventional transportation companies are starting to panic because of declining market share due to the emergence of online transportation networks, such as Uber, Didi Chuxing in China, Grab in Malaysia, and GO-JEK in Indonesia. Consumer interest arises when there are alternative choices before deciding (Suleman, Zuniarti, \& Sabil, 2019).

Marketing according to the American Marketing Association (AMA) Expert Directors is the process of organizing organizational activities to create, communicate, and offer products or services that have value for customers, partners, and the community at large. Meanwhile, according to Philip Kotler is the art and science of exploiting, creating, and providing value to 
meet the needs of a profitable market. Marketing identifies, measures and quantifies market sizes and identifies potential benefits. (Darmanto, 2016). Marketing according to (Kotler \& Keller, 2012) "Marketing is about identifying and meeting human social needs" which can be interpreted as marketing is about identifying and meeting human social needs

The habits of consumers consuming information are far different in seeking input and determining buying decisions (Suleman, 2014). This forces marketers to think hard to find alternative channels that are more effective in embracing consumers. Therefore, there comes a wave of diverse online interactive platforms, which aim to create a two-way and multidirectional dialogue. The decision making process by consumers is also more complicated due to the many parties that influence both offline and online (Kotler, Kartajaya, \& Huan, 2017). Online transportation such as Gojek, Uber and Grab are said to be the three main players in providing online transportation services. Gojek was first introduced in 2015 before other applications became an opening gate that introduces the public to this service. "More than half (51.1\%) of respondents claimed that Gojek was the first online transportation they used, followed by Grab (34.2\%) and Uber (14.4\%)," said the survey results as published by Shopback (Ayuwuragil , 2018).

Competition for changes in consumer behavior from offline to online is currently happening ((Suleman, Zuniarti, Marginingsih, et al., 2019). and can be said to be quite strict especially in the field of transportation. Data related to Go-Jek, Grab, and Uber is based on studies from One Data science with data sources obtained from comScore. Data on the number of unique visitors Grab and Gojek are not much different (8.6 million and 8.8 million per month). While the number of Uber users is around a quarter (2.3 million per month). Go-Jek has a user base of 8.8 million, while Grab has a user base of 8.6 million. 4 million of Go-Jek users also use Grab. Interestingly 15.8 percent and 16.9 percent of Go-Jek and Grab users, each also uses Uber. However, 60 percent of Uber users use Go-Jek and Grab. Based on data on the number of users by sex, Go-Jek has 3,403,000 male users and 5,468,000 female users (Iskandar, 2017). The need for changes in consumer behavior in conditions where a choice occurs competition (Suleman, Ali, Nusraningrum, \& Ali, 2019). because consumers in choosing will see several factors that change their attitudes more positively and subsequently this positive attitude will be able to make a decision to choose from a variety of choices exist (Suleman, Zuniarti, Setyaningsih, et al., 2019). The company continues to make efforts to increase customer loyalty. So, we need a strategy as a differentiation for each company in attracting consumer interest and in an effort to keep consumers in order to continue using the company's services in the future (Chan, Maharani, \& Tresna, 2017).

\section{THEORETICAL FRAMEWORK AND HYPOTHESES}

The design of this study is causal research, which explains causal relationships between research variables, carried out to determine the pattern of causal relationships from independent variables to the dependent variable. The variables used in the study are Service Quality as an independent variable, Consumer Satisfaction as the dependent variable, and Customer Value as an intervening variable. In this study, the objective to be obtained by researchers is to see how customer decisions are influenced by customer quality and value. shown below in Figure 1, in this study proposes a model to explore the direct relationship between quality and customer value on decisions and also develop research by examining the relationship of non-quality and consumer decisions through customer value. 
Figure 1. The study model

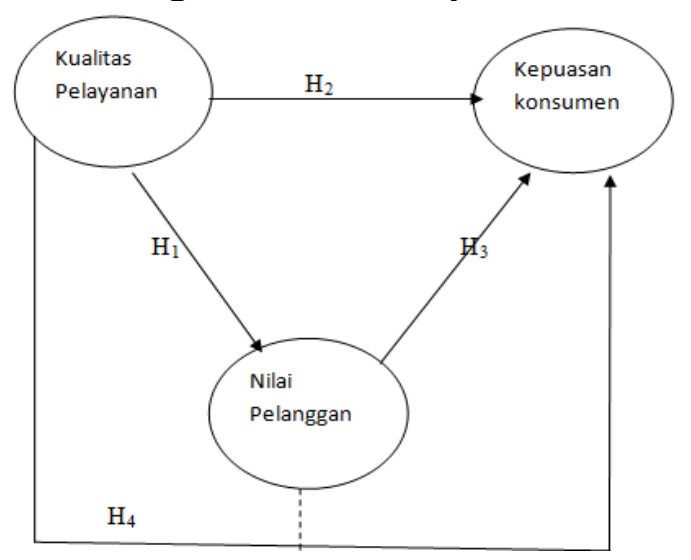

\section{Service quality}

According to Crosby quality is "conformance to requirements :, that quality must be assessed with focus and must try to understand customer expectations, so that the organization or company is expected to meet customer expectations by providing what consumers want. Parasuraman, et al. said that Service Quality is the basis for service marketing, because the core product being marketed is performance (which is quality), and performance is bought by customers, therefore quality of service performance is the basis for service marketing. The concept of good service will provide opportunities for companies to compete in winning consumers. While the good performance (quality) of a service concept creates a competitive situation where it can be implemented through strategies to convince customers, strengthen brands, and determine prices. (Ikasari, Suryoko, \& Nurseto, 2013). The definition of quality according to (Kotler \& Armstrong, 2014) is the overall characteristics and nature of a product or service that affects its ability to satisfy expressed or implied needs "

H1. Service quality affects customer value.

H2: Quality of service affects customer satisfaction.

\section{Customer Value}

According to (Kotler \& Keller, 2009) the perceived value of the customer is the difference between the customer's perspective assessment of all the benefits and costs of an offer against alternatives. According to the best in (Fatihudin \& Firmansyah, 2019) customer value is the benefit obtained by the customer minus the purchase cost. Customer value comes from economic benefits, customer benefits, and emotional benefits. Economic benefits stem from price advantages and costs other than purchase prices such as acquisition costs, use of ownership, maintenance, and repairs and disposal costs. Customer benefits come from the appearance of the product, service and reputation. Emotional benefits are product advantages in meeting the emotional needs of customers related to psychological needs, personality types of customers, and personal values of customers.

According to Tjiptono, a customer is an emotional bond that exists between the customer and the producer after the customer uses the company's products and services and finds that the product or service provides added value. Monroe stated that customer value is the ratio between benefits or perceived benefits and sacrifices incurred. Where the perceived benefits are a combination of physical attributes, service attributes and supporting techniques in product utilization. Sacrifices incurred are the total costs incurred by consumers including purchase costs and additional costs (such as the costs of ordering, transportation, installation, handling orders) as well as costs beyond purchase (replacing damage, risk of failure or poor service). In (Fatihudin \& Firmansyah, 2019). 


\section{Consumer Satisfaction}

Kotler and Keller (Kotler \& Keller, 2009) explain that consumer satisfaction is a feeling of pleasure or disappointment arising from comparing the performance of products or services produced against their expectations. Jesse Yu-Chen Lan, Nguyen Quang Vinh, Ha Thi Ngan (2016), "Analysis of Relationship among Service Quality, Customer Satisfaction, and Customer Loyalty with Hotel Industry in Hanoi Vietnam", the results of this study have a positive effect on service quality variables on customer satisfaction. Boonthadi Ratanavilaikul (2012), "Customer perceived value, satisfaction, and behavioral intentions in the logistics industry": a case study of ABC Express Worldwide (Thailand) CO., LTD, the results of this study Service quality has a significant effect on customer satisfaction.

H3. Customer value influences customer satisfaction

H4. Service quality affects customer satisfaction through customer value

Table 1. Summarized definition of constructs

\begin{tabular}{|c|c|c|c|}
\hline Variabel & Definisi & Dimensi & Indicator \\
\hline \multirow[t]{5}{*}{$\begin{array}{l}\text { Service } \\
\text { quality }\end{array}$} & \multirow{5}{*}{$\begin{array}{l}\text { Quality is a dynamic condition that affects } \\
\text { products, services, people, processes and } \\
\text { environments that meet or exceed } \\
\text { expectations. So that the definition of service } \\
\text { quality can be interpreted as an effort to meet } \\
\text { the needs and desires of consumers and the } \\
\text { accuracy of their delivery in offsetting } \\
\text { consumer expectations (Safitri, 2014). }\end{array}$} & $\begin{array}{l}\text { 1. Physical evidence } \\
\text { (tangible). }\end{array}$ & $\begin{array}{l}\text { 1. Taxibike Online provides facilities that } \\
\text { customers need. } \\
\text { 2. Neatness and politeness of taxibike } \\
\text { Online drivers }\end{array}$ \\
\hline & & 2. $\quad$ Empathy (Empathy) & $\begin{array}{l}\text { 1. The level of driver attention to the } \\
\text { customer. } \\
\text { 2. The level of seriousness of service. } \\
\text { 3. Taxibike Online drivers concern for } \\
\text { customers }\end{array}$ \\
\hline & & 3. Responsiveness. & $\begin{array}{l}\text { 1. Responsive in dealing with customer } \\
\text { complaints. } \\
\text { 2. Ease of ordering. }\end{array}$ \\
\hline & & 4. $\quad$ Reliability (reliability). & $\begin{array}{l}\text { 1. Taxibike Online avoids mistakes when } \\
\text { serving customers. } \\
\text { Taxibike Online establishes smooth } \\
\text { communication with customers. }\end{array}$ \\
\hline & & 5. Guarantee & $\begin{array}{l}\text { 1. Taxibike Online users are protected by } \\
\text { insurance. } \\
\text { 2. The accuracy of the driver to pick up the } \\
\text { customer. }\end{array}$ \\
\hline \multirow{4}{*}{$\begin{array}{l}\text { Customer } \\
\text { Value }\end{array}$} & \multirow{4}{*}{$\begin{array}{l}\text { Customer value is a comparison between the } \\
\text { benefits (benefits) felt by customers with the } \\
\text { costs (costs) incurred by customers to obtain } \\
\text { or consume these products, so customer value } \\
\text { is a preference felt by customers and an } \\
\text { evaluation of product attributes and various } \\
\text { consequences arising from use a product to } \\
\text { achieve customer goals and intentions } \\
\text { (Wooddruff in Diab, 2009). }\end{array}$} & 1. Emotional Value & 1. Having added value compared to others \\
\hline & & 2. Social Value & $\begin{array}{l}\text { 2. Improve the concept of social services to } \\
\text { consumers }\end{array}$ \\
\hline & & 3. $\quad$ Price/Value of Money. & $\begin{array}{l}\text { 1. Cost reduction / promo in taxibike Online } \\
\text { 2. Cost matching with benefits }\end{array}$ \\
\hline & & $\begin{array}{l}\text { 4. Quality/Performance } \\
\text { Value. }\end{array}$ & 1. Ease of using / obtaining services, \\
\hline \multirow[t]{3}{*}{$\begin{array}{l}\text { Consumer } \\
\text { Satisfaction }\end{array}$} & \multirow{3}{*}{$\begin{array}{l}\text { Tjiptono (in Napitupulu, 2015) customer } \\
\text { satisfaction is the core of achieving long-term } \\
\text { profitability. Satisfaction is the difference } \\
\text { between expectations and performance (which } \\
\text { is actually accepted). If expectations are high } \\
\text { while performance is low, satisfaction will not } \\
\text { be achieved. Satisfaction theory is always } \\
\text { based on efforts to eliminate or at least narrow } \\
\text { the gap between expectations and } \\
\text { performance. }\end{array}$} & 1. Perceived quality. & $\begin{array}{l}\text { 1. Good service provided at Taxibike } \\
\text { Online. }\end{array}$ \\
\hline & & 2. Perceived value. & $\begin{array}{l}\text { 1. Costs that must be incurred by } \\
\text { consumers to get company services. } \\
\text { 2. Customers have trust in service. }\end{array}$ \\
\hline & & 3. Customer expectations & $\begin{array}{l}\text { 1. Customer expectations are fulfilled as } \\
\text { satisfied with the price and Online } \\
\text { taxibike services. }\end{array}$ \\
\hline
\end{tabular}

\section{RESEARCH METHODS}

\section{Population and Samples}

When it was implemented in 2018, the subject of this research would be the residents of Pasar Manggis Village. The object of this study is the variable that is the subject of the variable service quality, customer value, and customer satisfaction. The population in this study is the Citizens of Pasar Manggis Urban Village. The population in the Pasar Manggis Village is 36,250 people / person. Taking the number of samples in this study using SEM analysis with calculations that refer to Hair et al (Wati, nd) ie the number of research indicators multiplied 
by 5 to 10 . Thus the sample for this study is the number of samples = number of indicators X 5 $=20 \times 5=100$ so the minimum number of samples is 100 samples.

Table 2. Demographic profile responden

\begin{tabular}{|c|l|c|c|}
\hline Measure & \multicolumn{1}{|c|}{ Items } & Frequency & $\%$ \\
\hline \multirow{3}{*}{ Gender } & Female & 59 & $59 \%$ \\
\cline { 2 - 4 } & Male & 41 & $41 \%$ \\
\hline \multirow{3}{*}{ Usia } & Single & 39 & $39 \%$ \\
\cline { 2 - 4 } & Married & 61 & $61 \%$ \\
\cline { 2 - 4 } & $17-20$ Year old & 28 & $28 \%$ \\
\cline { 2 - 4 } & $21-25$ Year old & 37 & $37 \%$ \\
\cline { 2 - 4 } & $26-29$ Year old & 19 & $19 \%$ \\
\cline { 2 - 4 } & $>30$ Year old & 16 & $16 \%$ \\
\hline
\end{tabular}

The results of the study based on the table above are known to the number of respondents is 100 respondents consisting of 59 female respondents 59\% and 41 male respondents $41 \%$. And based on the table above it is known that the number of respondents is 100 respondents consisting of 59 female respondents $59 \%$ and 41 male respondents $41 \%$. While the most common age group is between $21-25$ years as many as 37 respondents $37 \%$ and at least ages over 30 years as many as 16 respondents $16 \%$.

\section{DATA ANALYSIS DAN RESULTS}

In this study data analysis uses the Partial Least Square (PLS) approach. PLS is a Structural Equation Modeling (SEM) equation model based on components or variants. Structural Model or Inner Model Inner models (inner relations, structural models and substantive theory) describe the relationship between latent variables based on substantive theory. Structural models are evaluated using R-square for dependent constructs, Stone - Geisser Q-square test for predictive relevance and t test as well as the significance of the coefficient of structural path parameters, Measurement Model or Outer Model Convergent validity of the measurement model with the reflective model of indicators assessed based on correlation between itemcore / component score and construct score calculated by PLS. Reflective size is said to be high if it correlates more than 0.70 with the construct that is to be measured. However, for the early stages of research the development of a measurement scale of loading values 0.5 to 0.60 is considered sufficient. Hypothesis Test To test the hypotheses in this study, partial tstatistic values are used for each direct influence pathway.

To test the relationship between variables (hypothesis testing), the statistical value of the Smart PLS output is used which is compared with the value of the ttable and 5\% significant value of 1.96 (Ghozali \& Fuad, 2008). In statistical analysis, using least square partial regression (PLS) because researchers feel they prefer to use this technique than other techniques because it places minimum limits on sample size, scale of measurement, and residual distribution (Chin, 1998). It also combines the use of multiple linear regression and factor analysis to measure model parameters and model structure (Hsu, M.-H., Chuang, L.-W., \& Hsu, 2014). 


\section{Figure 2. Early PLS Algorithm Model}

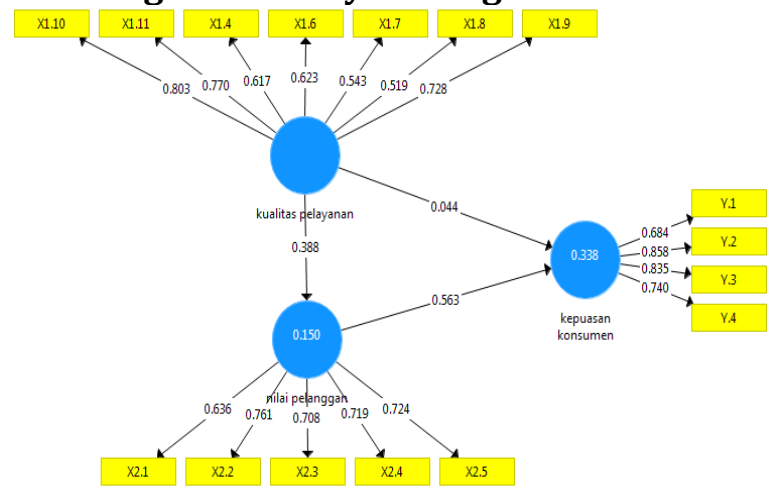

In the path analysis above, the equation model consists of two groups of constructs namely the exogenous construct and the endogenous construct. Exogenous constructs are variables that are not predicted by other variables in the model or also known as independent variables. In this study, exogenous constructs are service quality (KP) and endogenous constructs are factors predicted by one or several constructs. The construct can predict one or several other constructs, but exogenous constructs can only be related casually to endogenous constructs. In this study, what becomes an exogenous construct is customer value (NP), and what becomes an endogenous construct is consumer satisfaction (KK). After drawing a path diagram as above, then the next step is to analyze the data using Smart PLS software, by first testing the validity and reliability of the research variables.

Testing the validity and reliability of each question item using the help of SmartPLS 3.2 software. The individual reflexive measure is said to be valid if it has a loading value $(\alpha)$ with the latent variable to be measured $\geq 0.5$ The following is the output factor loading of the research variable on PLS.

Table 3. Measurement scales and factor loadings

\begin{tabular}{|c|c|c|c|c|c|c|}
\hline \multirow[b]{2}{*}{ Variable } & \multirow[b]{2}{*}{ Indicator } & \multirow[b]{2}{*}{ Loading } & \multicolumn{3}{|c|}{ Tstatistik } & \multirow[t]{2}{*}{ Information } \\
\hline & & & $\begin{array}{l}\text { Service } \\
\text { quality }\end{array}$ & $\begin{array}{l}\text { Customer } \\
\text { Value }\end{array}$ & $\begin{array}{l}\text { Consumer } \\
\text { Satisfaction }\end{array}$ & \\
\hline \multirow{7}{*}{$\begin{array}{l}\text { Service } \\
\text { quality }\end{array}$} & X.4 & 0,617 & 5,137 & & & \multirow{16}{*}{ Valid and significant } \\
\hline & X.6 & 0,623 & 6,116 & & & \\
\hline & X.7 & 0,543 & 5,069 & & & \\
\hline & X.8 & 0,519 & 4,424 & & & \\
\hline & $X .9$ & 0,728 & 11,109 & & & \\
\hline & X.10 & 0,803 & 16,011 & & & \\
\hline & X.11 & 0,770 & 12,829 & & & \\
\hline \multirow{5}{*}{$\begin{array}{l}\text { Customer } \\
\text { Value }\end{array}$} & Y.1 & 0,636 & & 6,946 & & \\
\hline & Y.2 & 0,761 & & 17,768 & & \\
\hline & Y.3 & 0,708 & & 9,993 & & \\
\hline & Y.4 & 0,719 & & 12,486 & & \\
\hline & Y.5 & 0,724 & & 7,909 & & \\
\hline \multirow{4}{*}{$\begin{array}{l}\text { Consumer } \\
\text { Satisfaction }\end{array}$} & Z.1 & 0,684 & & & 7,168 & \\
\hline & Z.2 & 0,858 & & & 27,965 & \\
\hline & Z.3 & 0,835 & & & 22,970 & \\
\hline & Z.4 & 0,740 & & & 7,435 & \\
\hline
\end{tabular}

\section{Pengujian Reabilitas}

Variabel dikatakan cukup reliabel bila mempunyai nilai construct reliability lebih besar dari 0,6 . Berikut ini adalah tabel hasil pengujian reliabilitas pada variabel penelitian 
Table 4. Construct Reliability and Convergent Validity

\begin{tabular}{|l|c|c|c|}
\hline Variabel & AVE & Compsite reliability & Cronbachs alpha \\
\hline Kualitas Pelayanan & 0,443 & 0,845 & 0,796 \\
\hline Nilai Pelanggan & 0,505 & 0,838 & 0,755 \\
\hline Kepuasan Konsumen & 0,612 & 0,862 & 0,789 \\
\hline
\end{tabular}

Based on the output reliability results above, that the variable service quality, customer value, and customer satisfaction have a composite reliability above 0.8 and Cronbach's alpha above 0.7 so that it can be concluded that the indicators used on each variable have good reliability or are able to measure the construct .

\section{Inner Model (Goodness Of Fit Model) ( $\mathbf{R}^{2}$ )}

Evaluation of the Goodness Of Fit Model is measured using predictive relevance (Q2) values. Predictive value relevance uses the following formula: $Q^{2}=1-\left(1-R^{2}{ }_{1}\right)\left(1-R^{2}\right)$

$$
\mathrm{Q}^{2}=1-(1-0,150)(1-0,338)
$$

$=1-(0,85)(0,662)$

$=1-(0,5627)$

$\mathrm{Q}^{2}=0,4373$

Where $\mathrm{R}^{2}{ }_{1}$ and $\mathrm{R}^{1}{ }_{2}$ are $\mathrm{R}$ square endogenous variables in the model. The interpretation of $\mathrm{Q}^{2}$ is the same as the coefficient of total determination in the path analysis (similar to $\mathrm{R}^{2}$ in the regression). $\mathrm{R}^{2}$ is the coefficient of determination which is part of the total variation in the dependent variable which is explained by variations in the independent variable. The following results of the analysis of the coefficient of determination of the research variables.

Table 5.Uji R Square

\begin{tabular}{|l|l|}
\hline Variable & R Square \\
\hline Customer Value & 0,150 \\
\hline Consumer Satisfaction & 0,338 \\
\hline Predictve Relevance (Q2) & 0,437 \\
\hline
\end{tabular}

Based on the research model above, the value $\left(\mathrm{R}^{2}\right)$ of the customer value variable is 0.150 , which means that the value indicates that customer value can be explained by the service quality variable by $15 \%$ while the remaining $85 \%$ is influenced by other variables not found in the study, customer satisfaction variable of 0.338 , which means that the value indicates that variations in customer satisfaction can be explained by the variable service quality and customer value by $33.8 \%$ while the remaining $66.2 \%$ is influenced by other variables not contained in the research model. Based on the value of prodictive relevance for the structural model in this study amounted to 0.437 or $43.7 \%$, meaning that the model is able to explain the phenomenon of consumer satisfaction associated with several variables, namely service quality and customer value. Therefore the model can be said to be very good, or the model has a very good predictive value. 


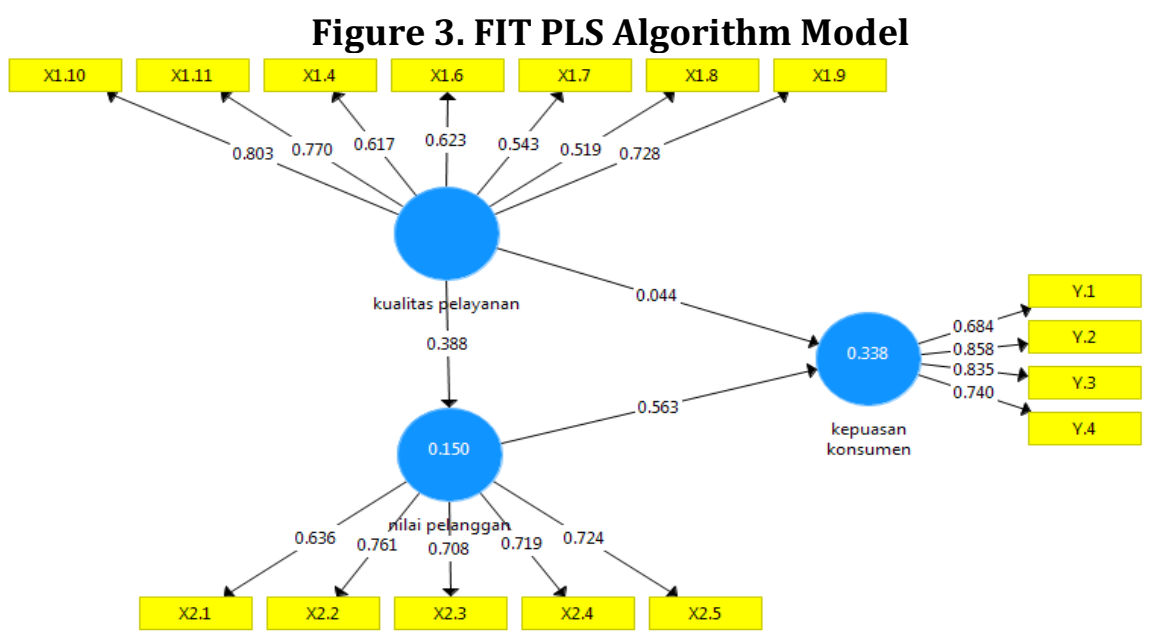

Based on the hypothesis testing path diagram above, not all indicators on each variable have a statistical $t$ value greater than 1.66 or $t$ table. To test the relationship between variables or test hypotheses, the statistical $t$ value of the smartPLS output is compared with the table value. The following is a table that provides the results of relationships between constructs or variables

Table 6. Hypothesis Test Result

\begin{tabular}{|l|c|c|c|c|}
\hline \multicolumn{1}{|c|}{ Relationship between Variables } & $\begin{array}{c}\text { Koefisien } \\
\text { parameter }\end{array}$ & T statisktik & P value & Information \\
\hline Service quality => customer value & 0,388 & 4,880 & 0,000 & Significant \\
\hline Service quality => consumer satisfaction & 0,044 & 0.379 & 0,352 & Not significant \\
\hline Customer value => consumer satisfaction & 0,563 & 6,240 & 0,000 & Significant \\
\hline $\begin{array}{l}\text { Service quality => customer satisfaction } \\
\text { through customer value }\end{array}$ & 0,218 & 3,689 & 0,000 & Significant \\
\hline
\end{tabular}

Path parameter coefficient obtained from the influence of service quality on customer value is 0.388 with a t value of statistics $4.880>1.64$ at the significance level $\alpha=0.05(5 \%)$ which states that there is a significant positive effect between service quality on customer value. The value of 0.388 on the parameter coefficient means that the better the quality of service, the better the value of the customer, this is in line with the first hypothesis that there is a significant positive effect between service quality variables on customer value.

The path parameter coefficient obtained from the effect of service quality on customer satisfaction is 0.044 with a t value of $0.379<1.64$ at the significance level $\alpha=0.05(5 \%)$ which states that there is a positive but not significant effect between service quality on customer satisfaction. The value of 0.044 on the parameter coefficient means that the better the quality of service, the satisfaction of consumers is increasing. It is also similar to the second hypothesis where there is a positive influence between service quality variables on customer satisfaction but this time it is not significant.

The path parameter coefficient obtained from the effect of customer value on consumer satisfaction is 0.563 with a statistical $t$ value of $6.240>1.64$ at the significance level $\alpha=0.05$ (5\%) which states that there is a significant positive effect between customer values on customers satisfaction. A value of 0.563 on the parameter coefficient means that the better the customer value is given, the customer satisfaction will increase. This is consistent with the third hypothesis that there is a significant positive influence between customer value variables on customer satisfaction. The path parameter coefficient obtained from the effect of service quality on customer satisfaction through customer value is 0.218 with a t value of statistics 
$3.689>1.64$ at the significance stage $\alpha=0.05(5 \%)$ which states that there is a positive influence dan significant between the quality of service to customer satisfaction. Value of 0.218 on the coefficient of parameters means that the better the quality of service performed, the more customer satisfaction will increase through customer value. This is consistent with the fourth hypothesis that there is a significant positive influence between service quality variables on customer satisfaction.

\section{DISCUSSIONS AND CONCLUSION}

In the research model, the effect of service quality on customer satisfaction has a small coefficient value when compared with customer value variables. This means that service quality has little effect on customer satisfaction compared to customer value which has a greater influence on customer satisfaction. This is also evidenced by hypothesis testing where the results of the influence of customer value on customer satisfaction have positive and significant results as well as service quality that has positive and significant results, unlike service quality variables that only have positive but not significant results.

Based on the results of research and discussion, the following conclusions can be drawn. Quality of service has a positive and significant effect on customer value, thus the better the quality of service provided by the taxi driver, the better the value will be given by the customer. quality of service has a positive but not significant effect on customer satisfaction, thus the quality of service is very influential because if the gojek driver provides good quality then the consumer will feel very satisfied. service quality has a positive and significant effect on customer satisfaction, thus the more positive value is given by the customer, the customer is satisfied. service quality has a positive and significant impact on customer satisfaction through customer value, thereby providing good quality it will increase customer satisfaction through customer value.

Based on the description above, the suggestions relating to the results of this study as follows in subsequent studies are advised to look at factors beyond service quality and customer value that influence customer satisfaction such as prices, and strategic promotions. For service quality factors have very little effect on customer satisfaction, therefore the online motorcycle taxi drivers need to improve the quality of service so that consumers feel satisfied. The next researcher is expected to be able to add other variables, samples and a wider population in the study.

\section{DAFTAR PUSTAKA}

Fatihudin, D., \& Firmansyah, A. (2019). Pemasaran Jasa (Pertama). Yogyakarta: CV Budi Utama.

Ghozali, I., \& Fuad. (2008). Structural Equation Modelling. Semarang.: Universitas Diponegoro.

Ikasari, A. U., Suryoko, S., \& Nurseto, S. (2013). PENGARUH NILAI PELANGGAN DAN KUALITAS PELAYANAN

TERHADAP KEPUASAN PELANGGAN (Studi kasus pada penumpang KA Kaligung Mas di Stasiun Poncol

Semarang). Diponegoro Journal of Social and Politic, 1-8.

Kotler, P., \& Amstrong, G. (2014). Priciples of Marketing (14th Editi). England: Person Horizon Edition.

Kotler, P., \& Keller, K. (2009). Manajemen Pemasaran. (Bob sabran, Ed.) (Ketiga Bel). Jakarta: Erlangga.

Suleman, D. (2014). PENGARUH KUALITAS PELAYANAN TERHADAP KEPUASAN KONSUMEN PADA RESTAURANT MY BENTO.

Suleman, D. (2018). Faktor penentu keputusan konsumen Indonesia memilih tempat belanja disebuah ecommerce (Theory of Planned Behavior). Jurnal Doktor Manajemen, Vol.1(No.1), pp 1-9.

Suleman, D., Ali, H., Nusraningrum, D., \& Ali, M. M. A. (2019). Perceived Ease of Use, Trust and Risk toward Attitude and Intention in Shopping for Online Fashion Products In Indonesia. Archives of Business Research, Vol.7(No.4), pp.240-253. https://doi.org/10.14738/abr.74.6482 
Suleman, D., Sutawidjaya, A. H., \& Kurniadi, I. (2018). Other Income from building a franchise system : Insight from the franchisor (pp. 1005-1012). Band. Retrieved from http://ieomsociety.org/ieom2018/proceedings/ ID 293

Suleman, D., Zuniarti, I., Marginingsih, R., Sabil, Nurhayaty, E., Rachmawati, S., ... Sari, I. (2019). Competition between offline and online stores: when it comes to shopping for fashion products, which store will be the choice of Indonesian consumers? In International Conference on Global Innovation and Trends in Economy (pp. 1-14). Jakarta. Retrieved from https://easychair.org/publications/preprint/8drP

Suleman, D., Zuniarti, I., \& Sabil. (2019). Consumer Decisions toward Fashion Product Shopping in Indonesia: The effects of Attitude, Perception of Ease of Use, Usefulness, and Trust. Management Dynamics in the Knowledge Economy, Vol.7(no.2), pp.133-146; https://doi.org/DOI 10.25019/MDKE/7.2.01

Suleman, D., Zuniarti, I., Setyaningsih, E. D., Yanti, V. A., Susilowati, I. H., Sari, I., ... Lestiningsih, A. S. (2019). DECISION MODEL BASED ON TECHNOLOGY ACCEPTANCE MODEL (TAM) FOR ONLINE SHOP CONSUMERS IN INDONESIA. Academy of Marketing Studies Journal, 23(4), Pp: 1-14.

Wati, L. N. (n.d.). Metodologi Penelitian Bisnis Terapan, Aplikasi SPSS, AVIEWS, Smart PLS, dan AMOS. Bandung: Percetakan Mujahid. 